\title{
Influence of man-made edaphotopes of the spoil heap on biota
}

\author{
Vasyl Popovych ${ }^{1 *}$, Oleksandr Kuzmenko ${ }^{2}$, Andrii Voloshchyshyn ${ }^{1}$, and Mykhailo Petlovanyi ${ }^{2}$ \\ ${ }^{1}$ Lviv State University of Life Safety, 35 Kleparyvska Str., 79007 Lviv, Ukraine \\ ${ }^{2}$ National Mining University, Department of Underground Mining, 19 Yavornytskoho Ave., \\ 49005 Dnipro, Ukraine
}

\begin{abstract}
The aim of the work is to investigate the influence of manmade edaphotopes of colliery spoil heap on biota by bioindication method. The physicochemical properties of edaphotopes were investigated: humidity, substrate temperature, humus content at different intervals of their depth and on different sections of the waste heap. The storage technologies of mineral waste in the dumps disregard its further use and transforming that occurs over time. It was revealed that on the northern slope exposures the greatest amount of moisture was concentrated and temperature regimes were acceptable for the activity of the soil biota, which was proved by the largest amount of biomass. New dependences of humus content in edaphotopes of the heap in different intervals of their depth from biomass of humus-forming organisms were established. Slight successional processes on the surface of the heap were observed, where young flora began to develop. This positive phenomenon will contribute to the humus of the genetic horizons and the development of tree and shrub vegetation. Favourable conditions for the development of neo-terrain and the formation of a new landscape in mining regions were confirmed.
\end{abstract}

\section{Introduction}

The development of mineral deposits is accompanied by mining works in rocks that doesn't contain commercial components, or their number is not profitable for different reasons. Mining technologies and technological parameters of development systems do not provide for the separate extraction and storage of mineral waste in heaps with their further use in other sectors of the economy over time. A lot of waste heaps are located in the Donetsk coal basin, where the extraction of coal beds is conducted in complicated geological conditions from ultrathin and thin $(0.65-1.2 \mathrm{~m})$ layers [1], which necessitates the continuous removal of rock and coal during development workings.

Thus, coal of the humite class, and sometimes sapropelitic-humic layers and rocks, represented by argillites, siltstones, sandstones, more rarely by limestones, fall into the waste heaps. These rocks are stored on the ground surface in significant volumes near or even close to mining enterprise, thus forming a specific relief. Waste heaps form a spoil tips

\footnotetext{
* Corresponding author: popovich2007@ukr.net
} 
up to $60-80 \mathrm{~m}$ high ridge-like (92\%), as well as flat (8\%). The rocks are heterogeneous in grain size distribution - from clay particles to boulders - containing wood, metal objects (pipes, wires, etc.) [2]. Mass of colliery spoils and shale deposits exceeds 18.7 billion tons.

In $[3,4]$ the authors mention that besides the planned waste of mining production, significant additional volumes of rock and minerals that peel off as a result of the stressdeformed rock and artificial solid mass conditions, are added to them. All of them fall into mine roadway and are winded on the ground surface under mining operations. Furthermore waste heaps, sludge and sediment located near the coal-preparation plants should be added. These rocks are more broken than in the waste heaps of mining enterprises. Large areas of the ground surface are taken out of circulation for their storage. For example, in the waste heaps of the Lviv-Volyn region 40.0 million cubic meters of gas have been accumulated. The area occupied by them is the second largest (320 hectares) after the Pokrovskyi district of the Donetsk region. Coal-bearing strata occupy $15 \%$ of the continent's territory [2]. Distribution of waste heaps of coal mines of Lviv-Volyn region by their volume and area is shown in Fig. 1.

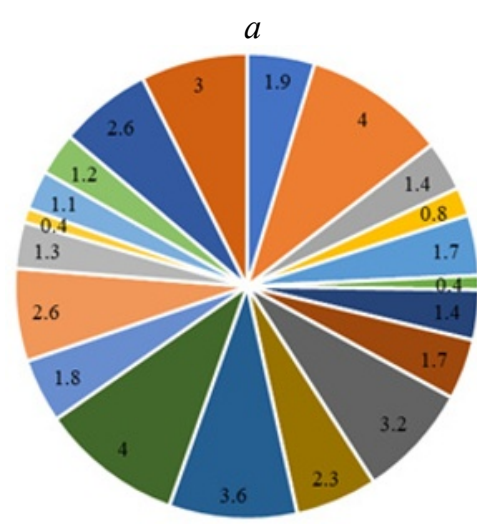

= Chervonohradska

" Lisova

- Velykomostivska $\# 3$

- Mezhyrichanska

= Velykom ostivska \#6

- Buzhanska

" Novovolynska \#9

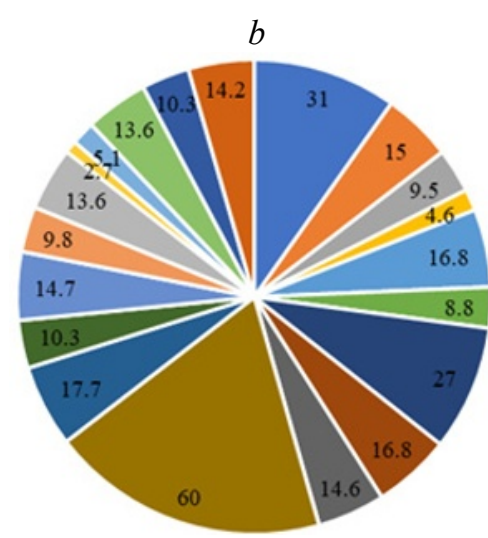

= Chervonohradska $\# 1$

" Vidrodzhennya

- Velykomostivska $\# 4$

- Vizeyska

" Bendyuzka

= Novovolynska $\# 4$

" Novovolynska \#5
" Stepova

- Velykomostivska

- Zarichna

- Nadiya

- Novovolynska $\# 10$

- Novovolynska $\# 1$

Fig. 1. Distribution of waste heaps of coal mines of Lviv-Volyn region by their volume in million $\mathrm{m}^{3}$ (a) and area in hectares (b).

Thus, an enclave of environmental pollution is formed in a separate industrial area, which by its volume affects the general sanitary state of the region and the distribution of atmospheric flows. Donetsk and Lviv-Volyn coal basin with the developed infrastructure of mining enterprises create a threatening situation that may transform into the zone of ecological disaster. The chemical composition of the spoil tip rocks is close to the rocks of the coal-bearing series of the Lviv-Volyn Basin [5] (Table 1).

This chemical composition of rocks is also characteristic of other waste heaps of the mines of this region. The rock is broken and most of the chemical elements that form complex geological structures interact with the atmosphere and sediments. Besides to the formation of new chemical compounds in the waste heaps, mined gases of $\mathrm{CH}_{4}, \mathrm{CO}_{2}, \mathrm{SiO}_{2}$, $\mathrm{CO}, \mathrm{TiO}_{2}$ and others, which rise to the ground surface through cracks and tectonic fractures, or during mining operations or carbonization of coal layers are added $[6,7]$. In the initial, 
active phase of the waste heaps, living creatures are almost absent, but there are transitional processes of rocks oxidation (the temperature of spoil tips combustion is $900-1300$ degrees), their transferring into a resting phase, which creates favorable conditions for the rebirth of invertebrate organisms.

Table 1. The chemical composition of the rocks in the waste heap of Chervonohradska mine [5].

\begin{tabular}{|l|c|c|c|c|c|c|c|c|c|c|}
\hline \multicolumn{1}{|c|}{ Mine rocks } & $\mathrm{SiO}_{2}$ & $\mathrm{Al}_{2} \mathrm{O}_{3}$ & $\mathrm{TiO}_{2}$ & $\mathrm{FeO}$ & $\mathrm{CaO}$ & $\mathrm{MgO}$ & $\begin{array}{c}\mathrm{K}_{2} \mathrm{O}+ \\
\mathrm{Na}_{2} \mathrm{O}\end{array}$ & $\mathrm{H}_{2} \mathrm{O}$ & $\mathrm{SO}_{3}$ & $\mathrm{P}_{2} \mathrm{O}_{5}$ \\
\hline Sandstone & $\begin{array}{c}75- \\
85\end{array}$ & $\begin{array}{c}5.7- \\
9.7\end{array}$ & $\begin{array}{c}0.2- \\
0.6\end{array}$ & $\begin{array}{c}2.7- \\
4.0\end{array}$ & $\begin{array}{c}0.1- \\
0.5\end{array}$ & $\begin{array}{c}0.4- \\
1.3\end{array}$ & $\begin{array}{c}0.9- \\
1.5\end{array}$ & $\begin{array}{c}1.8- \\
4.0\end{array}$ & $\begin{array}{c}0.1- \\
0.2\end{array}$ & $\begin{array}{c}0.0- \\
0.1\end{array}$ \\
\hline Claystone & $\begin{array}{c}49- \\
58\end{array}$ & $\begin{array}{c}9.6- \\
22.5\end{array}$ & $\begin{array}{c}0.4- \\
1.0\end{array}$ & $\begin{array}{c}8.8- \\
9.9\end{array}$ & $\begin{array}{c}0.7- \\
3.5\end{array}$ & $\begin{array}{c}1.2- \\
2.0\end{array}$ & $\begin{array}{c}1.2- \\
3.0\end{array}$ & $\begin{array}{c}1.9- \\
4.5\end{array}$ & $\begin{array}{c}0.2- \\
6.5\end{array}$ & $\begin{array}{c}0.2- \\
2.0\end{array}$ \\
\hline Siltite & $\begin{array}{c}49.8- \\
70\end{array}$ & $\begin{array}{c}16.2- \\
23.0\end{array}$ & $\begin{array}{c}0.8- \\
1.5\end{array}$ & $\begin{array}{c}1.2- \\
1.5\end{array}$ & $\begin{array}{c}0.7- \\
1.4\end{array}$ & $\begin{array}{c}0.8- \\
1.4\end{array}$ & $\begin{array}{c}1.5- \\
3.9\end{array}$ & $\begin{array}{c}0.5- \\
1.5\end{array}$ & $0-0.3$ & $\begin{array}{c}0.1- \\
0.5\end{array}$ \\
\hline Burnt rock & 60 & 22.7 & 1.0 & 8.0 & 0.8 & 1.5 & 2.5 & $2.5-$ & 0.95 & 0.1 \\
\hline $\begin{array}{l}\text { Weathered } \\
\text { rock }\end{array}$ & 38 & 16.5 & 0.8 & 10.5 & 0.8 & 1.9 & 2.2 & 27.9 & 0.55 & 0.6 \\
\hline $\begin{array}{l}\text { Unweathered } \\
\text { rock }\end{array}$ & 38.5 & 17.4 & 0.7 & 12.0 & 0.8 & 1.5 & 2.3 & 24.8 & 0.35 & 0.2 \\
\hline
\end{tabular}

\section{Aim, tasks and methods of research}

The aim of the work is the bioindication of man-made edaphotopes of coal mines waste heaps by the activity of its biota. According to the stated aim, the following tasks were set:

- to investigate the environmental safety in the area of coal mines waste heaps;

- to identify the main factors of increase of environmental hazard caused by waste heaps;

- to establish the basic physical and chemical properties of the rock refuse;

- to investigate the conditions for the development of land biota in the area of waste heaps influence.

The object of the study is the bioindication of the edaphic conditions of the spoil heaps for the development of the land biota.

The subject of the study is the peculiarities of the biomass formation, depending on the physico-chemical changes of the edaphotopes on the surface of the spoil heaps.

Methods of the research. In this work bioindicative methods of research, system analysis and methods of logistic constructions are used. The study of the life activity of the main species of edaphotopes biota was carried out according to the methods of M.S. Gilyarov [8]. The species of earthworms, as a bioindicator of edaphotopes, were determined by T.S. Perel's method [9].

For soil-zoological studies direct methods are used to determine the number of soil animals in the soil $\left(\right.$ on $1 \mathrm{~m}^{2}$ ). We have used the method of lit-by-lit digging and investigating of soil samples. The size of the samples was $0.25 \mathrm{~m}^{2}(50 \times 50 \mathrm{~cm})$. Samples were taken up to the lower level of invertebrates in the soil.

The sampling process is as follows: first, the area of the sample is marked by hammering the pegs in the corners of this square, then a fencing tape is passed through them. Then from the edges of the measured area the mortality and litter are bent in different directions. Dense fabric is spread near sample, where the soil selected from the sample is displaced.

At first, mortality, leaves, plant residues are displaced from the sample. They are handpicked and all fallen individuals are taken into account. 
The research was carried out in four - one digs the soil, two hand-pick the sample, one collects and describes the identified biotypes.

Instruments and materials: humidity meter $\mathrm{MG}-44, \mathrm{pH}-\mathrm{meter} \mathrm{KC}-300 \mathrm{~V}$, portable meteorological station "Kestrel-4000", dense fabric, fencing tape.

\section{Main part}

The research was carried out in the spoil heaps area of the Mezhyrichanska mine, that functioned in the Chervonohrad mining area (Lviv-Volyn coal basin).

Waste storage was carried out on two spoil heaps (1 - reclaimed, nonfunctioning). Currently there is 1 spoil heap. It should be noted that on the reclaimed heap natural reforestation processes take place. They are accompanied by the development of pioneer species - drooping birch, Scotch pine and bush grass. As the rock refuse is used for road construction frequent caving and shearing of the spoils are observed on the refuse dumps. An important negative environmental factor is that the mined rocks are weathered which causes the air polluting, rainwash and polluting of the soils.

Thus, the waste heaps of the Mezhyrichanska mine due to the violation of safe operating conditions are a powerful man-made factor of environmental pollution. On the spoil heaps, like on the devastated landscapes, specific edaphic and climatic conditions for the development of vegetation were established. The physicochemical and mechanical properties of edaphotopes in different parts of the waste heaps can vary significantly. The reason for such a phenomenon is the violation of the operation requirements of the waste heaps, the unevenness of spreading (or absence) of ground mixtures, chaotic disposal and accumulation of filtrate, etc. In such conditions, the successional processes proceed slowly, and in places where the land is aligned with bulldozers, they are absent at all. Detritophags the representatives of the soil fauna - play a significant role in humus generation and the edaphotope formation. The ecological conditions of the degraded landscapes have a powerful effect on the activity of the representatives of the soil fauna [10].

One of the most common bioindicators of environmental conditions are the following criteria: the number of individuals, the survival capacity, the degree of covers damage, the intensity of metabolism $[11,12]$. In some studies of technogenically polluted edaphotopes, a criterion of the rate of digging in the soil is used [13]. Investigation of the living organisms' activity will help to develop the processes of remediation and revegetation on the spoil heaps in order to reduce the harmful effects on the environment. Climatic and physico-chemical conditions are presented in scientific works $[14,15]$.

To study the biota's activity in the edaphotopes of the spoil heaps and adjoining area 5 sites were selected on the waste heap surface:

1 - top;

2 - northern slope exposition (middle tier);

3 - southern slope exposition (middle tier);

4 - western slope exposition (middle tier);

5 - east slope exposure (middle tier).

The chosen type of worm is Lumbricus terrestris.

It should be noted that according to the research methodology, the level of activity was investigated at 2 levels - in the depths of $0-10 \mathrm{~cm}$ and $10-20 \mathrm{~cm}$. Background values were collected in the area of meadow soil, which is located $1.5 \mathrm{~km}$ southward of the investigated waste heap.

As a result of erosion processes on the slopes the capacity of the humus horizon is lower, the content of phosphorus and potassium is lower, the hydrolytic acidity is higher, and the soil saturation at the bottom is low. An important factor of the medium is the acidity of the soil, the optimal ratio of the various species on agricultural land is almost 
neutral [16].

The $\mathrm{pH}$ reaction of the waste heap edaphotopes at a depth of $10 \mathrm{~cm}$ was slightly acidic and acidic. The highest humus index was found on the northern and western slope exposures (3.36 and 3.27\%). In the background soils, the humus content was $7.25 \%$. The highest humidity of the edaphotope was detected at the northern slope exposure $-86.7 \%$. The lowest humidity is on the southern exposure $(65.4 \%)$. The temperature of the substrate was the highest in the southern region $-+8.5^{\circ} \mathrm{C}$, and the lowest in the northern region -+ $6.5^{\circ} \mathrm{C}$ (Fig. 2).

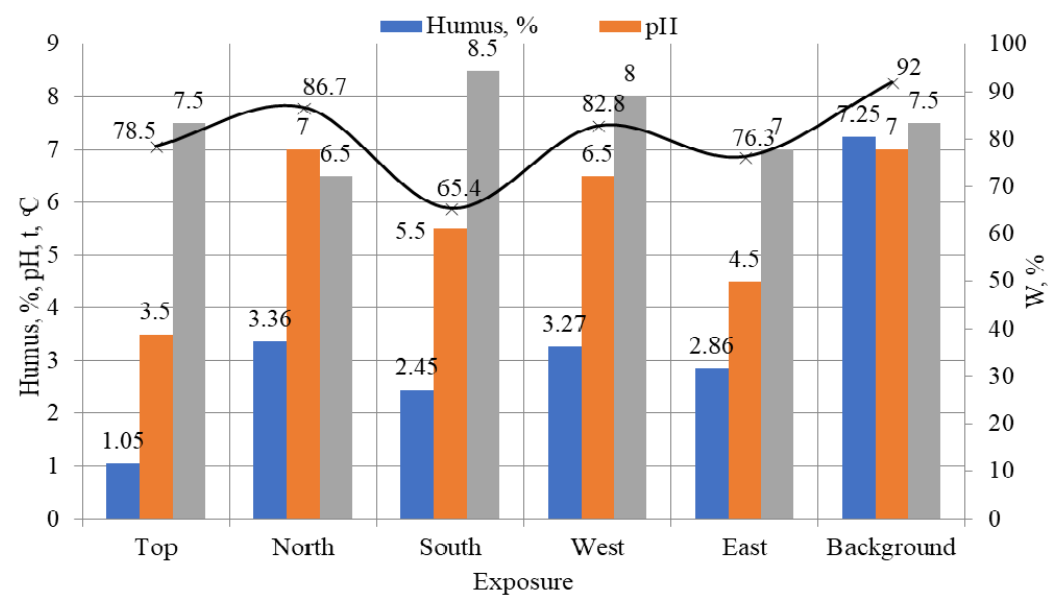

Fig. 2. Physicochemical properties of the waste heap edaphotope at a depth of $0-10 \mathrm{~cm}$.

The $\mathrm{pH}$ reaction of the waste heap edaphotopes at a depth of $20 \mathrm{~cm}$ was acidic. The highest humus index was found in the northern and western slope exposures $(1.15 \%$ and $1.1 \%$ ). In the background soils (depth up to $20 \mathrm{~cm}$ ) the humus content was $7.14 \%$. The highest humidity of the edaphotope was detected on the northern slope exposure $-74.8 \%$. The lowest humidity is in the eastern exposure (54.3\%). The temperature of the substrate was the highest in the southern region $-+6.5^{\circ} \mathrm{C}$, and the lowest in the eastern region was $+5^{\circ} \mathrm{C}$ (Fig. 3).

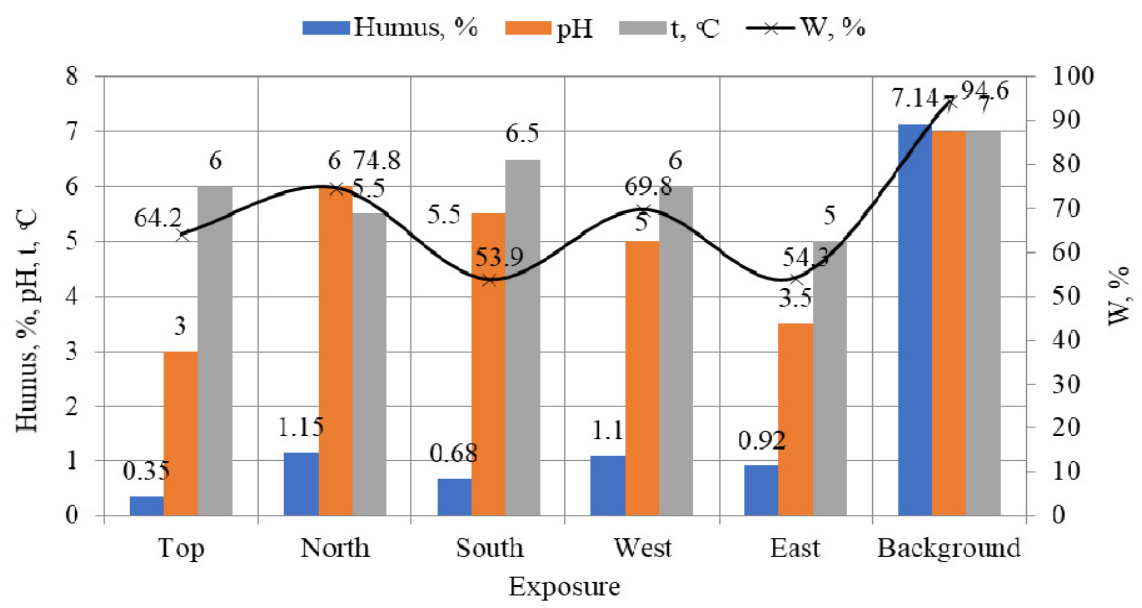

Fig. 3. Physicochemical properties of the waste heap edaphotope at a depth of $10-20 \mathrm{~cm}$. 
Taking into account the acidic reaction and the low temperature of the substrates of the earthworms colonies of in the waste heaps edaphotopes are inconsiderable. These data are supported by the following indicators. Since, on the northern slope exposure the highest humidity and acceptable temperature rates for the activity of earthworms are set, where their largest colonies are observed: at a depth of $10 \mathrm{~cm}-18$ pcs. with a biomass of $9.6 \mathrm{~g} / \mathrm{m}^{2}$; at a depth of $20 \mathrm{~cm}-7$ pcs. with a biomass of $4.8 \mathrm{~g} / \mathrm{m}^{2}$ (Fig. 4 and 5). In the southern and eastern exposures of the pine the investigated zoocenosis was not observed. The reason for this phenomenon is the drying of the substrate surface the by wind and solar radiation. In the background areas, the indicators of activity significantly exceed the conditions of artificial substrates and are as follows: at a depth of $10 \mathrm{~cm}-22$ pcs. with a biomass of $10.7 \mathrm{~g} / \mathrm{m}^{2}$; at a depth of $20 \mathrm{~cm}-25 \mathrm{pcs}$. with a biomass of $12.1 \mathrm{~g} / \mathrm{m}^{2}$.

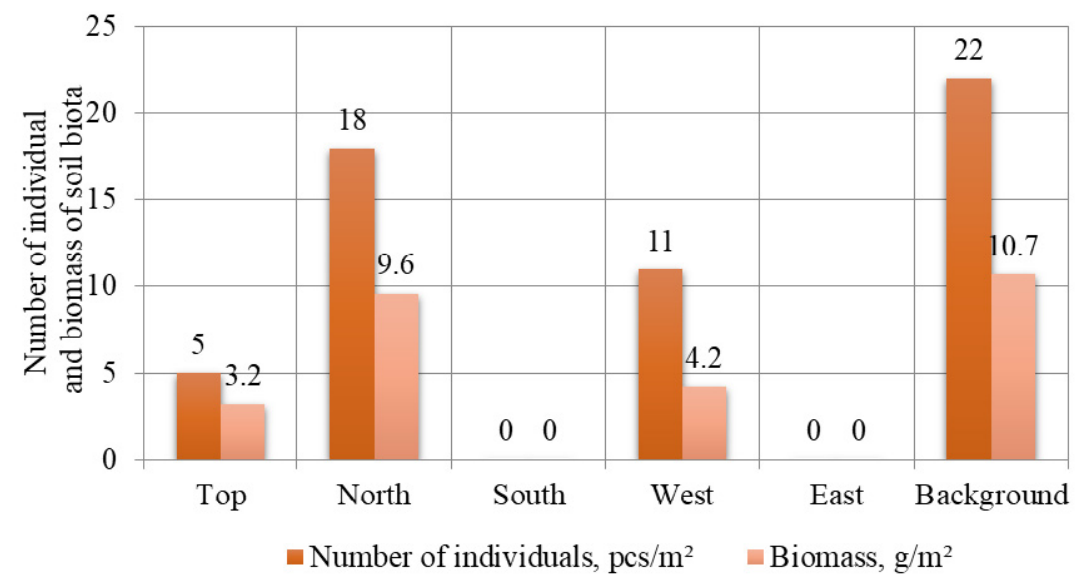

Fig. 4. The number of individuals of earthworms and their biomass at a depth of $0-10 \mathrm{~cm}$.

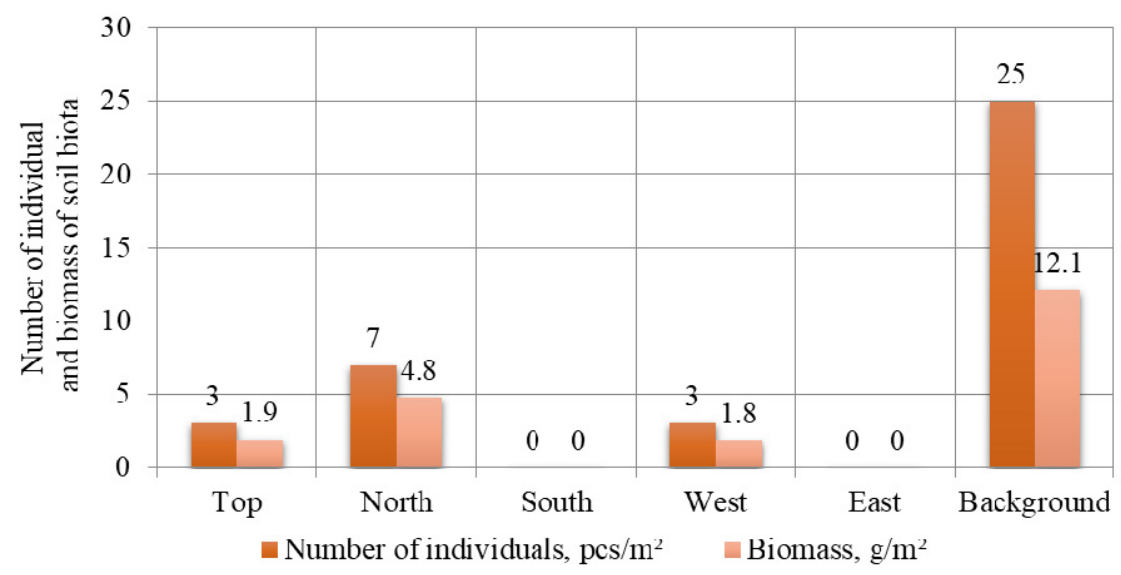

Fig. 5. The number of individuals of earthworms and their biomass at a depth of $10-20 \mathrm{~cm}$.

The obtained data on the activity of the earthworms and the content of humus in of their substrate give an opportunity to determine the dependence of humus content on the number of individuals (Fig. 6). 


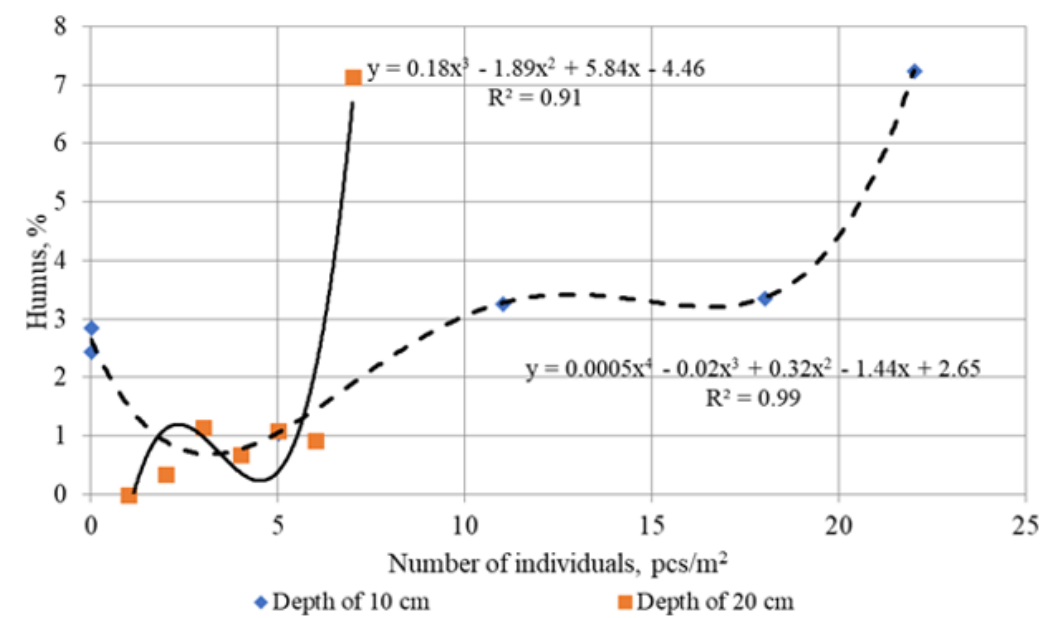

Fig. 6. Dependence of the humus content in the edaphotopes of the waste heap from biomass on the area of $1 \mathrm{~m}^{2}$.

The most important reasons for the absence of populations of living organisms in edaphotopes at different sites of the spoil heap are:

- high acidity of the waste heap edaphotopes;

- toxicity of the waste heap edaphotopes;

- high wind speed;

- slow rise of the neo-terrain and the light successional processes on the surface of the waste heap;

- landfalls and plump holes on the spoil heaps.

So, it can be stated that the technologies of underground mining are conducted without selective separation of rocks during their storage and the formation of artificial deposits. Gross waste storage is carried out without taking into account the chemical processes and the environmental activity. The forms and technological parameters of the storage of colliery waste don't take into account the further use of mineral raw materials for getting new biological resources for other important sectors of the economy.

\section{Conclusions}

It is recommended the separate storage of rocks on the ground surface near the mines, taking into account further processes of physical and chemical transformation for the effective use of improvements in the economy and landscape formation, causing the reduce of the environmental impact.

The zonal formation of the edaphic-climatic conditions for the development of flora has been established. It gives an opportunity to determine the order and way of application of newly created products on burned spoil heaps in various fields of the economy and converts the waste storage into secondary biological resources of the ecosystem. On the spoil heaps, as well as on the degraded landscapes, specific edaphic and climatic conditions for the development of vegetation were formed, and the physicochemical and mechanical properties of edaphotopes in different parts of the heaps may differ significantly. The reason for such a phenomenon is the violation of operation requirements of the waste heaps, the unevenness of spreading (or absence) of ground mixtures, chaotic disposal and accumulation of filtrate, etc. 
It was found that the highest humus index is in northern and western slope exposures (3.36 and 3.27\%). In the background soils, the humus content was $7.25 \%$. The highest humidity of the edaphotopes was detected on the northern slope exposure $-86.7 \%$. The lowest humidity is on the southern exposure $(65.4 \%)$. The temperature of the substrate was the highest on the southern section is $+8.5^{\circ} \mathrm{C}$, and the lowest in the northern area is $+6.5^{\circ} \mathrm{C}$. The presence of sedimentary rocks and humus coal in the mining waste during the oxidation process creates favorable conditions for the development of neo-relief and the new landscape formation in mining regions.

The formation conditions of the waste heaps edaphotopes are revealed. It is important for development of their mining and biological reclamation. Thus, during the miningengineering recultivation is the possibility of adjusting the parameters of the fertile soil layer, which is being applied in the last thing, taking into account the properties of the already formed edaphotopes on the surface of the waste heap as a result of the complex physical and chemical transformations. At the stage of biological reclamation, while choosing of the artificial forest plantations, attention should be paid to certain species of tree and shrub vegetation adapted to the waste heap edaphotopes and have a high regenerative capacity.

The authors express their gratitude to Prof. Kucheriavyi V.P. for valuable advices and ideas expressed during the researches.

\section{References}

1. Kuz'menko, A., Pochepov, V., \& Ryabychev, V. (2010). Dependence of effectiveness of development of mining operations on processibility of coal seams deposits with thickness of $1.2 \mathrm{~m}$. New Techniques and Technologies in Mining, 51-55. https://doi.org/10.1201/b11329-10

2. Maksimovich, N.G., \& Gorbunova, K.A. (1991). Geokhimicheskie izmeneniya geologicheskoy sredy pri razrabotke ugol'nykh mestorozhdeniy. Geologiya i razvedka, (5), 137-140.

3. Kuz'menko, A., Furman, A., \& Usatyy, V. (2010). Improvement of mining methods with consolidating stowing of iron-ore deposits on big depths. New Techniques and Technologies in Mining, 131-136. https://doi.org/10.1201/b11329-22

4. Kuz'menko, O., Petlyovanyy, M., \& Stupnik, M. (2013). The influence of fine particles of binding materials on the strength properties of hardening backfill. Annual Scientific-Technical Collection - Mining of Mineral Deposits, 45-48. https://doi.org/10.1201/b16354-10

5. Knysh, I.B. (2015). Heokhimichni doslidzhennia porid terykonu shakhty "Chervonohradska" Lvivsko-Volynskoho baseinu. V Materialakh XI naukovo-praktychnoi konferentsii "Suchasna heolohichna nauka i praktyka $v$ doslidzhenniakh studentiv i molodykh fakhivtsiv” (pp. 82-86). Kryvyi Rih: Kryvorizkyi natsionalnyi universytet.

6. Falshtynskyi, V., Saik, P., Lozynskyi, V., Dychkovskyi, R., \& Petlovanyi, M. (2018). Innovative Aspects of Underground Coal Gasification Technology in Mine Conditions. Mining of Mineral Deposits, 12(2), 68-75. https://doi.org/10.15407/mining12.02.068

7. Khomenko, O., Kononenko, M., Myronova, I., \& Sudakov, A. (2018). Increasing ecological safety during underground mining of iron-ore deposits deposits. Naukovyi Visnyk Natsionalnoho Hirnychoho Universytetu, (2), 29-38. doi:10.29202/nvngu/2018-2/3

8. Gilyarov, M.S. (1975). Uchet krupnykh pochvennykh bespozvonochnykh (mezofauny). Metody pochvenno-zoologicheskikh issledovaniy, 12-29.

9. Perel', T.S. (1976). Kriticheskiy analiz sistemy Lumbricidae (s opredelitel'noy tablitsey rodov fauny SSSR). Zoologicheskiy zhurnal, 36(6), 823-836.

10. Kucheriavyi, V.P. (2010). Zahalna ekolohiia. Lviv: Svit.

11. Kibardin, V.M., \& Zherebtsov, A.K. (1990). Vliyanie neftyanogo zagryazneniya na dozhdevykh chervey. V Materialakh VI nauchnoy konferentsii molodykh uchenykh Kazanskogo instituta 
biologii (pp. 230-232). Kazan’: Kazanskiy filial Akademii nauk SSSR.

12. Popovych, V.V. (2015). Bioindykatsiia edafichnykh umov smittiezvalyshch za dopomohoiu vyvchennia zhyttiediialnosti doshchovykh cherviakiv. V Tezakh dopovidei III Mizhnarodnoi naukovo-praktychnoi konferentsii "Novitni dosiahnennia biotekhnolohii ta nanofarmakolohii" (pp. 93-94). Lviv: Mehaprynt.

13. Kuz'min, Ye.V. (2008). Skorost' zakapyvaniya i vyzhivaemost' dozhdevykh chervey v usloviyakh neftyanogo zagryazneniya razlichnoy intensivnosti. V Materialakh IV nauchnoprakticheskoy konferentsii "Aktual'nye problemy ekologii Yaroslavskoy oblasti” (pp. 297-301). Izdanie VVO REA.

14. Popovych, V.V. (2008). Doslidzhennia fizyko-khimichnykh vlastyvostei hruntiv i perehorilykh porid na terykonakh Novovolynskoho hirnychopromyslovoho raionu. Naukovyi Visnyk Natsionalnoho Lvivskoho Tekhnichnoho Universytetu Ukrainy, 18(12), 258-264.

15. Popovych, V.V. (2009). Vplyv klimatychnykh umov na rozvytok roslynnosti tekhnohennykh landshaftiv Maloho Polissia u zymovyi period. Naukovyi Visnyk Natsionalnoho Lvivskoho Tekhnichnoho Universytetu Ukrainy, 19(3), 37-42.

16. Petrov, V.S. (1946). Aktivnaya reaktsiya pochvy $(\mathrm{pH})$ kak faktor rasprostraneniya dozhdevykh chervey (Lumbricidae, Oligocheta). Zoologicheskiy zhurnal, 25(2). 107-110. 